DOI: $\underline{10.35619 / \text { iiu.v1i14.424 }}$

Марчук Галина старший викладач кафедри дошкільної педагогіки і психології та спеціальної освіти імені проф. Т. І. Поніманської Рівненського державного гуманітарного університету,

м. Рівне, Україна

ORCID: 0000-0002-4907-5340

e-mail: galyna.marchuk@gmail.com

\title{
ГОТОВНІСТЬ МАЙБУТНІХ ВИХОВАТЕЛІВ ДО ФОРМУВАННЯ СОЦІАЛЬНОЇ КОМПЕТЕНТНОСТІ СТАРШИХ ДОШКІЛЬНИКІВ
}

Анотація. Стаття присвячена аналізу особливостей формування соціальної компетентності дітей дошкільного віку. Проблема соціальної компетентності дошкільнят - одна 3 найактуальніших. Розв'язання іiі, 3 одного боку, допоможе здійснити системний, цілісний підхід до розвитку дитини, 3 другого - співвіднести цей розвиток з життям. Сучасна система освіти та виховання намагається втілити гуманістичні ідеали виховання досконалої людини, вільної здатної жити і творчо діяти в умовах змінного соціуму. Виховання гуманної особистості виступає на перший план сучасної освіти.

Загальні підходи до формування соціальної компетентності дитини визначаються принципами гуманізації виховання - олюдненні виховних стосунків, визнанні цінності дитини як особистості, ії значущості в суспільстві, заснованої на усвідомленні своїх зв'язків з навколишнім і в цілому - місця у дорослому світі. Такий підхід відповідає загальній меті виховання формуванню цілісної, гуманної особистості, орієнтованої на відтворення цінностей національної та загальнолюдської культури, саморозвиток і моральну саморегуляцію поведінки. 3 огляду на це особливої значущості набуває проблема становлення соціальної компетентності старших дошкільників. На сучасному етапі розвитку освіти мають місце суперечності між процесом формування соціально-активної особистості та умовами іiі соціалізації, тому, перш за все, доцільно посилити увагу на необхідності підготовки майбутніх вихователів, до успішної реалізації процесу соціалізації особистості дошкільного віку. У статті розкрито компоненти готовності майбутніх вихователів до формування соціальної компетентності старших дошкільників, виокремлено педагогічні умови для покращення стану готовності майбутніх вихователів до формування соціальної компетентності старших дошкільників.

Ключові слова: соціалізація, соціальна компетентність, професійна підготовка вихователів, старші дошкільники.

Постановка проблеми. Сучасне суспільство вимагає оновлення всіх сфер соціального життя, модернізацію системи вищої освіти та передбачає 


\section{Інноватика у вихованні. Випуск 14. 2021.}

якісно нову підготовку педагога в галузі дошкільної освіти. Загальновідомо, що саме професіоналізм вихователя, його фахова компетентність сприяють соціалізації дошкільників. Формування соціальної компетентності дошкільників виступає сьогодні на передній план пріоритетних проблем, які потребують пильної уваги батьків, педагогів і всього суспільства. Про це свідчать нормативно-правові документи: Закон України «Про дошкільну освіту», Національна доктрина розвитку освіти України у XXI столітті, Базовий компонент дошкільної освіти в Україні. В процесі соціалізації дитина адаптується до умов життя, навчається дотримуватися норм та вимог, засвоювати доцільні правила, переносити свої знання в нові умови, набуває досвіду. Отже, цілеспрямована соціалізація - важлива складова повноцінного розвитку особистості.

Дитинство на всіх етапах характеризується постійною орієнтацією на дорослий світ, потребою прилучення до соціуму, взаємодії 3 ним. Дошкільний вік виступає початковим етапом формування суб'єкта діяльності, спілкування та пізнання. Значення періоду «народження вступ до школи» полягає в набутті вихідних людських знань і умінь, психічних якостей і властивостей, необхідних людині для життя в суспільстві.

В психолого-педагогічній науці останнього десятиріччя написано багато наукових праць, присвячених аналізу особливостей формування соціальної компетентності дошкільнят. Однак залишаються недостатньо вивченими особливості й основні напрями діяльності закладів дошкільної освіти щодо формування в дітей старшого дошкільного віку соціальної компетентності як важливого складника соціального розвитку дитини.

Таким чином, сучасні умови породжують низку суперечностей між суспільною потребою покращення соціального виховання дітей дошкільного віку і недостатньою ефективністю суспільного виховання в цьому процесі; між необхідністю формування соціальної компетентності дошкільників та відсутністю методики забезпечення.

Аналіз практики дозволяє констатувати наявність проблеми забезпечення закладів дошкільної освіти вихователями, які володіють на досить високому рівні вміннями формування соціальної компетентності вихованців. Виникає необхідність формування у майбутніх педагогів закладів дошкільної освіти професійно-педагогічних знань, умінь, навичок формування соціальної компетентності дітей.

У зв’язку 3 тим, що професійна діяльність педагога закладу дошкільної освіти - це цілісний процес і забезпечується не окремими предметними знаннями, а їх системою, виникає необхідність інтеграції підготовки майбутніх вихователів до формування соціальної компетентності вихованців 3 навчальними предметами, включеними в зміст професійної підготовки студентів закладу вищої освіти.

Аналіз останніх досліджень 3 проблеми. У психолого-педагогічній науці виконано багато наукових досліджень, присвячених аналізу 


\section{Інноватика у вихованні. Випуск 14. 2021.}

проблеми соціалізації дошкільників. У цих роботах обгрунтовано загальні положення і основи вказаної проблеми (С. Козлова, О. Кононко, Т. Поніманська, А. Богуш, Л. Варяниця, Н. Гавриш, С. Курінна, I. Рогальська).

Аналіз соціально-педагогічних досліджень свідчить про інтерес учених до проблеми ранньої соціалізації дітей. Розроблено вітчизняні та зарубіжні концепції соціалізації особистості. Визначено соціальнопедагогічні умови формування соціальних уявлень, методи впливу на становлення позитивних взаємин однолітків (В. Абраменкова, А. Капська, С. Козлова, О. Кононко, С. Куліковська, С. Литвиненко, А. Мудрик, I. Рогальська, В. Ямницький та ін.).

У дослідженнях українських і зарубіжних науковців останніх років висвітлено проблему професійної підготовки вихователів закладів дошкільної освіти (Л. Артемова, Г. Бєлєнька, Е. Бєлкіна, А. Богуш, Н. Бібік, Н. Гавриш, І. Дичківська, Л. Коваль, Р. Кондратенко О. Кононко, К. Крутій, I. Рогальська, Т. Поніманська, Н. Кічук, Н. Лисенко, Н. Манжелій, Т. Науменко, В. Пабат, Л. Покроєва, О. Поліщук, Т. Танько та ін.).

Майбутнім педагогам дошкільної освіти (вихователям, методистам, педагогам додаткової освіти) відводиться особлива увага. Це обумовлено унікальністю періоду дошкільного віку і тими завданнями, які вирішує сьогодні сучасна дошкільна освіта. Необхідність акцентувати увагу на підготовці педагога дошкільної освіти пов'язана з тим, що саме в закладах вищої освіти здійснюють підготовку фахівців до безпосередньої роботи 3 дітьми (Богініч, 2009).

Мета статті - розкрити особливості готовності майбутніх вихователів до формування соціальної компетентності старших дошкільників.

Виклад основного матеріалу дослідження. Проблема підготовки майбутніх вихователів до педагогічної діяльності висвітлена в працях провідних учених з дошкільної педагогіки та психології Л. Артемової, Є. Барбіної, А. Богуш, Н. Грабовець, С. Кулачківської, Т. Поніманської, I. Рогальської.

Термін «готовність» традиційно тлумачать як результат процесу підготовки, а підготовку - як процес, під час якого формується готовність особистості до діяльності. Проте як синонім уживається паралельно 3 поняттям «готовність» термін «підготовленість». Науковці у цьому випадку послуговуються принципом диференціації: стан психологічної готовності - це тимчасова готовність, а підготовленість особистості довготривала готовність.

Термін «професійна підготовка» у «Педагогічному словнику» (Гончаренко, 1997, с.262) пояснюється як сукупність спеціальних знань, умінь і навичок, якостей особистості, трудового досвіду і норм поведінки, що забезпечують можливість здійснення успішної праці за обраною професією.

Сьогоденням висуваються нові вимоги до дошкільної освіти загалом та до кожного вихователя зокрема. Педагоги мають бути творчими 


\section{Інноватика у вихованні. Випуск 14. 2021.}

особистостями, новаторами ідей, постійно підвищувати свій професійний рівень. Розвиток педагогічного колективу залежатиме від здатності розв'язувати професійні та особистісні проблеми кожним учасником педагогічного процесу. Усвідомлення самого себе, виявлення особистісного начала через колективну співпрацю стимулює перехід до «простору спроможності» розв'язувати різноманітні проблеми (Капська, 1998, c.67).

Найбільш важливим періодом соціалізації є дошкільний вік, коли дитина не лише набуває знання, формує власний світогляд, але й отримує навички самоконтролю, взаємодії з колективом, вміння вирішувати складні життєві ситуації. Саме в навчально-виховному процесі відбувається розвиток усіх складових самовдосконалення особистості, насамперед потреби у самоствердженні та самореалізації, що $€$ невід'ємною частиною соціального становлення сучасної людини. Кінцевою метою виховання особистості $\epsilon$ іiі підготовка до виконання комплексу ролей, необхідний для суспільного життя: громадянина, трудівника, громадського діяча, сім'янина, товариша. В процесі соціалізації дитина дошкільного віку долучається до соціального довкілля (Кононко,2009).

Соціалізація особистості в дошкільному дитинстві $є$ пріоритетним напрямом дошкільної освіти, важливим системним педагогічно виваженим процесом, пролонгованим у часі, у змістовному та технологічному аспектах, що дозволяє дитині прилучатися до соціокультурного процесу та освоювати позицію суб'єкта соціального життя (Рогальська, 2008).

Це дозволило нам виявити відсутність чіткої системи у плануванні відповідної роботи з соціалізації дошкільників, недостатню сформованість знань, умінь і навичок студенів для ефективної соціалізації дітей, нами було виокремлено низку педагогічних умов для вирішення цієї проблеми.

Ефективність готовності майбутніх вихователів до формування соціальної компетентності старших дошкільників залежить від низки педагогічних умов.

Отже, ми виокремили такі педагогічні умови для покращення стану готовності майбутніх вихователів до формування соціальної компетентності дітей дошкільного віку:

оволодіння студентами знаннями й уміннями, які передбачають інтеграцію дитини у соціальне середовище;

формування практичних умінь і навичок студентів здійснювати процес формування соціальної компетентності дітей дошкільного віку, а також основ гармонійного світосприймання;

оволодіння майбутніми педагогами умінням самостійно здобувати знання.

Запропоновані педагогічні умови перебувають у тісному взаємозв'язку. Їх дотримання в освітньому процесі закладу вищої освіти сприятиме формуванню готовності майбутніх вихователів до розвитку соціальної компетентності у дітей старшого дошкільного віку. Зміст цих умов визначається цілями, завданнями, характером майбутньої фахової діяльності та становить єдність теоретичної, 


\section{Інноватика у вихованні. Випуск 14. 2021.}

практичної та мотиваційної підготовленості випускника закладу вищої освіти здійснювати професійну діяльність.

До структури готовності майбутнього педагога дошкільної освіти ми включити такі п'ять складових:

1) мотиваційний компонент (професійна спрямованість майбутніх вихователів ЗДО до формування соціальної компетентності старших дошкільників, сформованість мотивів, потреб у їх використанні);

2) змістовий компонент (опанування педагогічними, методичними, теоретичними i практичними знаннями 3 формування соціальної компетентності та їх використання в освітньому процесі закладу дошкільної освіти);

3) операційний компонент (сформованість у майбутніх педагогів дошкільної ланки освіти педагогічних та методичних умінь і навичок щодо формування соціальної компетентності старших дошкільників);

4) рефлексивний компонент (сформованість мотивів, потреб у застосуванні рефлексії на заняттях, опанування психолого-педагогічними, методичними знаннями, уміннями, навичками 3 рефлексії та їі застосування в освітньому процесі закладу дошкільної освіти під час занять, обізнаність щодо вікових та індивідуальних особливостей старших дошкільників);

5) інтеграційний компонент (обізнаність щодо власних i потенційних можливостей старших дошкільників у процесі становлення їх соціальної компетентності; здатність створювати індивідуально прийнятну методику формування соціальної компетентності у дітей старшого дошкільного віку).

Проаналізувавши навчальні плани підготовки спеціалістів 3 дошкільної освіти зі спеціальності «Дошкільна освіта», ми виокремили дисципліни, які сприяють оволодінню майбутніми вихователями необхідними знаннями про соціалізацію та визначають зміст конкретних знань $з$ проблем формування соціальної компетентності дошкільників, а також дають можливість синтезувати інформацію стосовно професійної спрямованості. Це «Дошкільна педагогіка», «Дитяча психологія», «Методика роботи з родинами», «Методика ознайомлення 3 соціальним довкіллям».

Інтеграція змісту фахових дисциплін у процесі підготовки майбутніх вихователів до формування соціальної компетентності старших дошкільників дозволила реалізацію першої педагогічної умови, а саме, оволодіння здобувачами вищої освіти знаннями й уміннями, які передбачають інтеграцію дитини у соціальне середовище.

Компонентами системи професійно-педагогічної готовності майбутніх вихователів до формування соціальної компетентності дошкільників є мета, функції, структура, зміст, форми і методи їі реалізації, контроль. Рівень їх розробленості, взаємодії один з одним в результаті реалізації цієї системи визначає ефективність підготовки спеціалістів. 


\section{Інноватика у вихованні. Випуск 14. 2021.}

Висновки і перспективи подальших розвідок. Новий підхід щодо створення системи професійно-педагогічної підготовки майбутніх вихователів до формування соціальної компетентності дошкільників зорієнтований на розвиток практичних умінь і навичок здобувачів вищої освіти здійснювати процес формування соціальної компетентності дітей дошкільного віку, а також основ гармонійного світосприймання дошкільників.

Перспективу подальших наукових розвідок вбачаємо в розробці моделі та технологій підготовки майбутніх вихователів до формування соціального досвіду дітей дошкільного віку.

\section{СПИСОК ВИКОРИСТАНИХ ДЖЕРЕЛ}

Богініч, О., Борисова, З., Загарницька І. (ред.). (2009). Підготовка вихователя до розвитку особистості дитини в дошкільному віиі: монографія. Київ: Вид-во НПУ імені М. П. Драгоманова, 310 с.

Гончаренко, С. (1997). Украӥнський педагогічний словник. Київ: Либідь, 376 с.

Капська, А. (ред.). (1998). Деякі особливості формування готовності студентів до професійної творчості. Моделювання виховної діяльності в системі професійної підготовки студентів: теорія, практика, програми. Київ: ІЗМН, 192 с.

Кононко, О. (2009). Виховуємо соиіально компетентного дошкільника: навч.метод. посіб. до Базової програми розвитку дитини дошкільного віку «Я у світі». Київ, 201с.

Рогальська, I. (2008). Соиіалізаиія особистості у дошкільному дитинстві: специфіка, сутність: монографія. Київ: Міленіум. 400 с.

\section{REFERENCES}

Bohinich, O., Borysova, Z., Zaharnytska I. (red.). (2009). Pidhotovka vykhovatelia do rozvytku osobystosti dytyny $v$ doshkilnomu vitsi: monohrafiia [Training the educator for the development of the child's personality in preschool age]. Kyiv: Vyd-vo NPU imeni M. P. Drahomanova, 310 s. [in Ukrainian].

Honcharenko, S. (1997). Ukrainskyi pedahohichnyi slovnyk [Ukrainian pedagogical dictionary]. Kyiv: Lybid, 376 s. [in Ukrainian].

Kapska, A. (red.). (1998). Deiaki osoblyvosti formuvannia hotovnosti studentiv do profesiinoi tvorchosti [Some features of the formation of students' readiness for professional creativity]. Modeliuvannia vykhovnoi diialnosti $v$ systemi profesiinoi pidhotovky studentiv: teoriia, praktyka, prohramy. Kyiv: IZMN, 192 s. [in Ukrainian].

Kononko, O. (2009). Vykhovuiemo sotsialno kompetentnoho doshkilnyka [We bring up a socially competent preschooler] : navch.-metod. posib. do Bazovoi prohramy rozvytku dytyny doshkilnoho viku "Ia u sviti". Kyiv, 201s. [in Ukrainian].

Rohalska, I. (2008). Sotsializatsiia osobystosti u doshkilnomu dytynstvi: spetsyfika, sutnist : monohrafiia [Socialization of personality in preschool childhood: specifics, essence: monograph]. Kyiv: Milenium. 400 s. [in Ukrainian]. 


\section{Інноватика у вихованні. Випуск 14. 2021.}

\section{READYNESS OF THE FUTURE EDUCATORS FOR THE SOCIAL COMPETENCE FORMATION OF SENIOR PRESCHOOLERS}

\section{Marchuk Halyna}

Senior Lecturer at the professor T. I. Ponimanska Department of

Preschool Pedagogy

and Psychology and Special Education,

Rivne State University for the Humanities,

Rivne, Ukraine

ORCID: 0000-0002-4907-5340

e-mail: galyna.marchuk@gmail.com

Abstract. The article is devoted to the analysis of features social competence formation of the preschool age children. The problem of social competence of preschool children is one of the most topical. On the one hand, the solving of it will help to implement a systematic, holistic approach to child development, on the other - will help to correlate this development with life. The modern system of education and upbringing tries to embody the humanistic ideals of the education of a perfect person, a free personality, to be able to live and act creatively in a changing society. The upbringing of such a person is the main task. General approaches to the formation of social competence of the child are determined by the principles of humanization education - the humanization in education relations, the recognizing the value of the child as a person, its importance in society, based on awareness of their relationships with the other people and in general - its place in humanity. This approach corresponds to the general purpose of the education - the formation of a holistic, humane personality, who is focused on the reproduction of the values of the national and universal culture in the creative life, self-development and moral self-regulation of behavior. In this case, the problem of the social competence formation of the older preschoolers becomes especially important. As at the present stage of the development of the education there are the contradictions between the process of the formation of the socially active personality and the conditions of its socialization, so, first of all, it is necessary to pay more attention to the training of the future educators. The author payed more attention to the necessarity to prepare future educators for their successful implementation to the process of the preschool personality's socialization. The components of readiness of future educators for the formation of social competence of senior preschoolers are revealed, pedagogical conditions for improving the state of readiness of future educators for the formation of social competence of senior preschoolers are singled out. It was disclosed the components of future educators readiness for the formation of the social competence in the senior preschoolers, it was separated the pedagogical conditions how to improve the readiness of future educators for the formation of social competence in senior preschoolers.

Keywords: socialization, social competence, professional education of kindergarten teachers, pre-school children.

Стаття надійшла до редакиії 21.09.2021р. 